\author{
G. Lannig · L.G. Eckerle - I. Serendero \\ F.-J. Sartoris $\cdot$ T. Fischer · R. Knust - T. Johansen \\ H.-O. Pörtner
}

\title{
Temperature adaptation in eurythermal cod (Gadus morhua): a comparison of mitochondrial enzyme capacities in boreal and Arctic populations
}

Received: 8 April 2002 / Accepted: 19 September 2002 / Published online: 30 November 2002

(C) Springer-Verlag 2002

\begin{abstract}
Activities of citrate synthase (CS), cytochrome $c$ oxidase (CCO) and the electron transport system (ETS) were investigated in white muscle and liver of laboratory-maintained cod, Gadus morhua, from the North Sea, Norwegian coast and Barents Sea for an analysis of temperature acclimation and adaptation in aerobic metabolism. Cold acclimation within each population led to elevated activities of CS, CCO and ETS in white muscle. In liver, however, only North Sea cod showed cold-compensated CS activities, with CCO and ETS unchanged. In contrast, cold-acclimated Norwegian cod displayed unchanged enzyme activities, and Arctic cod showed elevated activities for CS, but decreased activities for CCO and no change in ETS. Between-population comparisons revealed clear evidence for permanent cold adaptation in white muscle of northern (Norwegian coast and Barents Sea) compared to boreal (North Sea) cod populations, reflected by higher activities of CS, CCO and ETS at the same acclimation temperature. Cold-compensated, mass-specific enzyme activities in liver were found in northern compared to boreal cod for CS and CCO, however, for ETS, after warm acclimation only. When evaluated as capacity in total liver, such activities were only found in northern populations in the case of CS at all temperatures, and for CCO and ETS at $15^{\circ} \mathrm{C}$ only. Hepatosomatic index $\left(I_{\mathrm{H}}\right)$ and liver lipid contents were highest in North Sea cod, with similar $I_{\mathrm{H}}$ but lower lipid contents in cold- versus warm-acclimated animals. An acclimation effect on $I_{\mathrm{H}}$ was found in
\end{abstract}

Communicated by O. Kinne, Oldendorf/Luhe

G. Lannig · L.G. Eckerle · I. Serendero · F.-J. Sartoris

T. Fischer $\cdot$ R. Knust $\cdot$ H.-O. Pörtner $(\bowtie)$

Alfred-Wegener-Institute for Marine and Polar Research,

Columbusstrasse, 27568 Bremerhaven, Germany

E-mail: hpoertner@awi-bremerhaven.de

Tel.: + 49-471-48311307

Fax: + 49-471-48311149

T. Johansen

Fisheries and Marine Biology, University of Bergen, Norway
Norwegian cod only, with higher $I_{\mathrm{H}}$ but unchanged lipid contents in the cold. In conclusion, permanent cold adaptation of muscle aerobic metabolism prevails in cod populations at higher latitudes, which is in line with permanently elevated rates of oxygen consumption observed in a parallel study. These differences reflect higher maintenance costs in cold-adapted versus cold-acclimated cod.

\section{Introduction}

Temperature is a crucial environmental factor setting the limits for life and influencing the activity of organisms including the rates of growth and reproduction. Fish live in environments with temperatures ranging from around $-1.9^{\circ} \mathrm{C}$ in polar waters to about $34^{\circ} \mathrm{C}$ in the tropics. Living in polar oceans goes hand in hand with small annual temperature variations. Since low temperatures depress metabolic rates and performance levels, compensatory physiological adjustments may occur. Many poikilotherms have the ability to adjust the rates of biological function by using homeokinetic mechanisms. Enhanced enzyme activities are found in cold-acclimated as well as in cold-adapted animals (Torres and Somero 1988; Crockett and Sidell 1990; Sokolova and Pörtner 2001; Kawall et al. 2002). Alterations in intracellular ionic and membrane phospholipid compositions, quantitative alterations of functional protein levels, functional differences between isozymes (Hochachka and Somero 1984), an increase in mitochondrial densities (Egginton and Sidell 1989; Johnston et al. 1998) or cristae densities (St-Pierre et al. 1998) and/or in organ size [Kent et al. 1988 (liver and heart); Seddon and Prosser 1997 (liver)] have been reported to compensate for the effects of low temperatures.

The adjustment of aerobic scope, reflected by mitochondrial densities and capacities, is identified as a crucial step in thermal adaptation, and mitochondrial enzyme levels are an important determinant of aerobic capacity for ATP production. These adjustments are 
suggested to differ between cold-acclimated and coldadapted as well as between cold-eurythermal and coldstenothermal animals (Pörtner et al. 2000; Pörtner 2002a). Cold-eurythermal species are predominantly found in the Northern Hemisphere, as the fauna in Arctic oceans has a much younger evolutionary history with respect to cold adaptation than that in Antarctic seas and is less isolated from adjacent seas. Accordingly, some species in sub-Arctic and Arctic waters may still be in transition to life in the permanent cold, while those in the Antarctic have developed features of permanent cold adaptation over millions of years (Pörtner 2002a).

For a comparison of the effects of cold acclimation versus cold adaptation in eurythermal fish the present study was designed to investigate the degree of cold compensation of aerobic enzyme activities in white muscle and liver tissue of three cod populations (Gadus morhua) in a latitudinal cline between the southern North Sea (NC), the Norwegian coast (NCC) and the northeastern Arctic or Barents Sea (NEAC). According to recent evidence these populations are genetically distinct (Nielsen et al. 2001), a finding likely related to their different spawning sites, but possibly, also to life in different climates. The cod population from the North Sea experiences large seasonal temperature fluctuations between $6^{\circ} \mathrm{C}$ and $14^{\circ} \mathrm{C}$, whereas cold-adapted cod from the Norwegian coast and Arctic live in more stable, colder habitats, at temperatures between $5^{\circ} \mathrm{C}$ and $8^{\circ} \mathrm{C}$ for NCC and $2^{\circ} \mathrm{C}$ and $4^{\circ} \mathrm{C}$ for NEAC (J.W. Dippner, personal communication). The comparison of sub-populations of the same species in a latitudinal cline should avoid pitfalls associated with comparisons of aerobic capacities between different, distantly related fish species. To estimate metabolic activity, enzyme capacities of aerobic metabolism were analyzed: citrate synthase (CS), an indicator for citric acid cycle activity; the so-called ETS (electron transport system), which comprises the activity of two enzymes of the respiratory chain, NADH oxidase and cytochrome $b$ reductase (complex I and III); as well as cytochrome $c$ oxidase (CCO), which represents complex IV.

\section{Materials and methods}

Animals and experimental procedure

Gadus morhua of three populations, southern North Sea cod (NC), Norwegian coastal cod (NCC) and northeastern Arctic cod (NEAC) were acclimated to different temperatures $(4,8,12$ and $15^{\circ} \mathrm{C}$, except for NEAC which was only acclimated to 8,12 and $15^{\circ} \mathrm{C}$ ). Fishes were tagged individually and fed ad libitum for growth rate analysis (NCC and NEAC with commercial food pellets (NorAqua) and NC with sprats, as these cod refused to feed on the food pellets. Experiments with offspring from broodstocks of NCC and NEAC were carried out at the University of Bergen between 18 January 1999 and 7 March 2000 at $4^{\circ} \mathrm{C}$ and $12^{\circ} \mathrm{C}$ and between 27 May 1998 and 5 March 1999 at $8^{\circ} \mathrm{C}, 12^{\circ} \mathrm{C}$ and $15^{\circ} \mathrm{C}$. A growth experiment with $\mathrm{NC}$ was carried out on the island of Helgoland (Alfred-Wegener-Institute) between 8 July and 9 September, 1999, with cod caught in the German Bight in spring 1999. At the end of the growth experiments, the fish were killed at an age between 1 and 2 years and samples of white axial muscle and liver were frozen in liquid nitrogen. Final body and liver mass, condition and gonadosomatic indices of the experimental fish are summarized in Table 1.

\section{Analyses}

Samples of white axial muscle and liver, of female cods only, were prepared for homogenization by grinding in a mortar under liquid nitrogen. CS activity was measured using a modification of the
Table 1 Gadus morhua. Final body and liver mass, condition indices ( $k$-factor), hepatosomatic indices $\left(I_{\mathrm{H}}\right)$ and gonadosomatic indices $\left(I_{\mathrm{G}}\right)$ of cod from different acclimation groups and populations. Data are means $\pm \mathrm{SD}$; liver masses and $I_{\mathrm{H}}$ are only given for fishes used for the determination of liver composition and enzyme activities

\begin{tabular}{|c|c|c|c|}
\hline & North Sea cod & Norwegian coastal cod & Northeastern Arctic cod \\
\hline$(n)$ & $(7-9)$ & $(6-19)$ & $(5-10)$ \\
\hline \multicolumn{4}{|c|}{ Body mass (g) } \\
\hline $4^{\circ} \mathrm{C}$ & $292 \pm 96$ & $996 \pm 217$ & \\
\hline $8^{\circ} \mathrm{C}$ & $371 \pm 99$ & $1422 \pm 372$ & $1349 \pm 503$ \\
\hline $12^{\circ} \mathrm{C}$ & $434 \pm 193$ & $1441 \pm 431$ & $1395 \pm 535$ \\
\hline $15^{\circ} \mathrm{C}$ & $342 \pm 46$ & $1038 \pm 191$ & $787 \pm 256$ \\
\hline \multicolumn{4}{|c|}{ Liver mass (g) } \\
\hline $4^{\circ} \mathrm{C}$ & $25.8 \pm 5.8$ & $85.9 \pm 33.3$ & \\
\hline $8^{\circ} \mathrm{C}$ & $38.9 \pm 11.2$ & $124.7 \pm 38.8$ & $85.7 \pm 76.9$ \\
\hline $12^{\circ} \mathrm{C}$ & $47.6 \pm 23.7$ & $105.6 \pm 66.6$ & $100.1 \pm 91.5$ \\
\hline $15^{\circ} \mathrm{C}$ & $34.5 \pm 8.0$ & $62.5 \pm 39.3$ & $35.5 \pm 28.4$ \\
\hline \multicolumn{4}{|l|}{$k$-factor } \\
\hline $4^{\circ} \mathrm{C}$ & $1.0 \pm 0.1$ & $1.2 \pm 0.1$ & \\
\hline $8^{\circ} \mathrm{C}$ & $1.0 \pm 0.1$ & $1.4 \pm 0.2$ & $1.1 \pm 0.2$ \\
\hline $12^{\circ} \mathrm{C}$ & $1.1 \pm 0.1$ & $1.4 \pm 0.3$ & $1.2 \pm 0.1$ \\
\hline $15^{\circ} \mathrm{C}$ & $1.0 \pm 0.1$ & $1.4 \pm 0.1$ & $1.1 \pm 0.1$ \\
\hline \multicolumn{4}{|c|}{ Hepatosomatic index $\left(I_{\mathrm{H}}\right)$} \\
\hline $4^{\circ} \mathrm{C}$ & $10.0 \pm 1.3$ & $8.2 \pm 1.8$ & \\
\hline $8^{\circ} \mathrm{C}$ & $10.5 \pm 1.4$ & $8.5 \pm 1.2$ & $5.9 \pm 3.2$ \\
\hline $12^{\circ} \mathrm{C}$ & $10.8 \pm 0.9$ & $6.7 \pm 2.3$ & $5.2 \pm 2.4$ \\
\hline $15^{\circ} \mathrm{C}$ & $9.9 \pm 1.2$ & $5.4 \pm 2.6$ & $4.3 \pm 1.9$ \\
\hline \multicolumn{4}{|c|}{ Gonadosomatic index $\left(I_{\mathrm{G}}\right)$} \\
\hline $4^{\circ} \mathrm{C}$ & $0.3 \pm 0.1$ & $2.2 \pm 0.9$ & \\
\hline $8^{\circ} \mathrm{C}$ & $0.4 \pm 0.1$ & $11.6 \pm 4.4$ & $3.7 \pm 1.9$ \\
\hline $12^{\circ} \mathrm{C}$ & $0.4 \pm 0.1$ & $11.5 \pm 7.3$ & $4.3 \pm 2.2$ \\
\hline $15^{\circ} \mathrm{C}$ & $0.4 \pm 0.1$ & $11.5 \pm 3.0$ & $2.5 \pm 1.1$ \\
\hline
\end{tabular}


procedure from Sidell et al. (1987): tissue powder (approximately $125 \mathrm{mg})$ was placed in 9 vol of buffer $(75 \mathrm{mM}$ Tris- $\mathrm{HCl}, \mathrm{pH} 7.6$, $1 \mathrm{mM}$ EDTA) and mixed briefly using a vortex. After $5 \mathrm{~min}$ of ultrasonic treatment at $0^{\circ} \mathrm{C}$ (output control 8, duty cycle $50 \%$, Branson Sonifier 450), the samples were centrifuged at $9500 \mathrm{~g}$ for $10 \mathrm{~min}$ at $0^{\circ} \mathrm{C}$ and the extract was withdrawn from below the fatty layer. The effect of this procedure on dilution factors was taken into account for all enzymes (see below). CS activity was determined in $100 \mathrm{mM}$ Tris$\mathrm{HCl}$ buffer ( $\mathrm{pH} 8$ ), containing $5 \mathrm{mM}$ DTNB, $20 \mathrm{mM}$ acetyl-CoA and $20 \mathrm{mM}$ oxaloacetate. Absorbance at $\lambda=412 \mathrm{~nm}$ was monitored in a thermostatted spectrophotometer (Beckman DU 7400) at 5, 8, 12,15 and $18^{\circ} \mathrm{C}$. For tissues from $\mathrm{NC}$ and for all liver samples, measurements were performed at 5,12 and $18^{\circ} \mathrm{C}$ only. CS activities, expressed in units per gram tissue wet mass were calculated using an extinction coefficient $\left(\epsilon_{412}\right)$ for CS of $13.611 \mathrm{mmol}^{-1} \mathrm{~cm}^{-1}$.

For CCO determinations, powdered tissue (approximately $125 \mathrm{mg}$ ) was briefly homogenized with an Ultra Turrax in $9 \mathrm{vol}$ of buffer (20 mM Tris-HCl, pH 7.4, 1 mM ETDA, 0.1\% Tween 20) according to Hardewig et al. (1999). In contrast to muscle samples, liver samples were centrifuged for $10 \mathrm{~min}$ at $1000 \mathrm{~g}$ and $0^{\circ} \mathrm{C}$ and the extract was withdrawn from below the fatty layer by use of a syringe. CCO activity was measured according to Moyes et al. (1997) in a buffer containing $20 \mathrm{mM}$ Tris- $\mathrm{HCl}$ at $\mathrm{pH} 8,0.5 \%$ Tween 20 and $50 \mu \mathrm{M}$ reduced cytochrome $c$. Cytochrome $c$ was dissolved in $20 \mathrm{mM}$ Tris- $\mathrm{HCl}$ at $\mathrm{pH} 8$ and reduced by the addition of sodium dithionite, which was removed by gel filtration in a Sephadex G-25 column (Hardewig et al. 1999). CCO activity was measured by monitoring the decrease in extinction at $550 \mathrm{~nm}$. Activity, expressed in units per gram wet mass, was calculated using an extinction coefficient $\left(\epsilon_{550}\right)$ of $19.11 \mathrm{mmol}^{-1} \mathrm{~cm}^{-1}$.

The method for measuring ETS activity was modified from Madon et al. (1998). Powdered tissue (approximately $30 \mathrm{mg}$ ) was homogenized with an Ultra Turrax in 200 vol of $0.1 \mathrm{M}$ phosphate buffer at $\mathrm{pH} 8.5,0.75 \mathrm{mM} \mathrm{MgSO}_{4}$ and $0.2 \%$ Triton X-100 and centrifuged for $10 \mathrm{~min}$ at $300 \mathrm{~g}$ and $0^{\circ} \mathrm{C}$, and the extract was withdrawn from below the fatty layer. ETS activity was determined in $0.1 \mathrm{M}$ phosphate buffer at $\mathrm{pH} 8.5,0.85 \mathrm{mM}$ NADH, $2 \mathrm{mM}$ INT [2-(p-jodophenyl)-3-(p-notrophenyl)-5-phenyl-tetrazoliumchlorid] and $0.03 \%$ Triton X-100 by following the reduction of INT, which yields an increase in absorbance at $490 \mathrm{~nm}$. ETS activity, in units per gram tissue wet mass, was calculated using an extinction coefficient $\left(\epsilon_{490}\right)$ of $15.91 \mathrm{mmol}^{-1} \mathrm{~cm}^{-1}$.

$\mathrm{CCO}$ and ETS activities were determined in a thermostatted spectrophotometer (Beckman DU 7400) at 2, 5, 8, 12, 15 and $18^{\circ} \mathrm{C}$ for white muscle and at $12^{\circ} \mathrm{C}$ for liver. For ETS measurements, a significant decrease in enzyme activity occurred over time; therefore, a fresh extract was prepared for analysis at each temperature.

Total lipid, water and protein content of liver were determined for all populations at $4{ }^{\circ} \mathrm{C}$ and $12^{\circ} \mathrm{C}$ acclimation temperatures. Total lipid content of liver was measured by the chloroform-methanolwater method of Bligh and Dyer (1959). To obtain hepatic water content, pieces of liver were oven dried at $60^{\circ} \mathrm{C}$ to constant mass. The results of total lipid and water content of liver are expressed as a percentage of liver wet mass. Total protein content of liver was estimated after subtraction of lipid and water contents from $100 \%$ and was also expressed as a percentage of liver wet mass.

\section{Allometric scaling}

Body and liver mass varied strongly between individual fishes and populations (see Table 1 for original data) and, accordingly, allometric relationships may have influenced the levels and comparisons of enzyme activities. To eliminate the effect of body mass on muscle-specific enzyme activities, values measured for white muscle were converted to enzyme activities expected for a fish weighing $1.2 \mathrm{~kg}$, using a formula modified after Pelletier et al. (1993):

- normalized activity $=$ measured activity $\times(1.2 / \text { body mass })^{m}$,

where $m$ is the slope of the linear regression in a double logarithmic plot of enzyme activity per gram tissue against body mass in kilograms. Since experimental body-mass ranges were too small to detect significant relationships, values of $m$ were adopted from Pelletier et al. (1993), who determined -0.22 for CS and -0.31 for CCO in white muscle of Atlantic cod (G. morhua) captured in the St. Lawrence estuary, near Matane (Quebec). The same factor as for CCO was used to estimate the normalized activity of ETS. In our own experiment similar, but non-significant slopes, were found for NCC (largest dataset) of -0.23 for CS with $P=0.3286,-0.23$ for CCO with $P=0.1249$ and -0.15 for ETS with $P=0.4815$.

A significant negative relationship was found between enzyme activities per gram liver and total liver wet mass. Accordingly, livermass-specific enzyme activities were converted to specific enzyme activities expected for a liver weighing $40 \mathrm{~g}$ by use of the following formula:

- normalized activity $=$ measured specific activity $\times(40 /$ liver mass $)^{m}$,

where the liver mass exponent $m$ was determined from the slope of the linear regression of measured enzyme activity per gram liver wet mass versus liver mass in grams in a double logarithmic plot (Fig. 1). Furthermore, since specific enzyme activities are

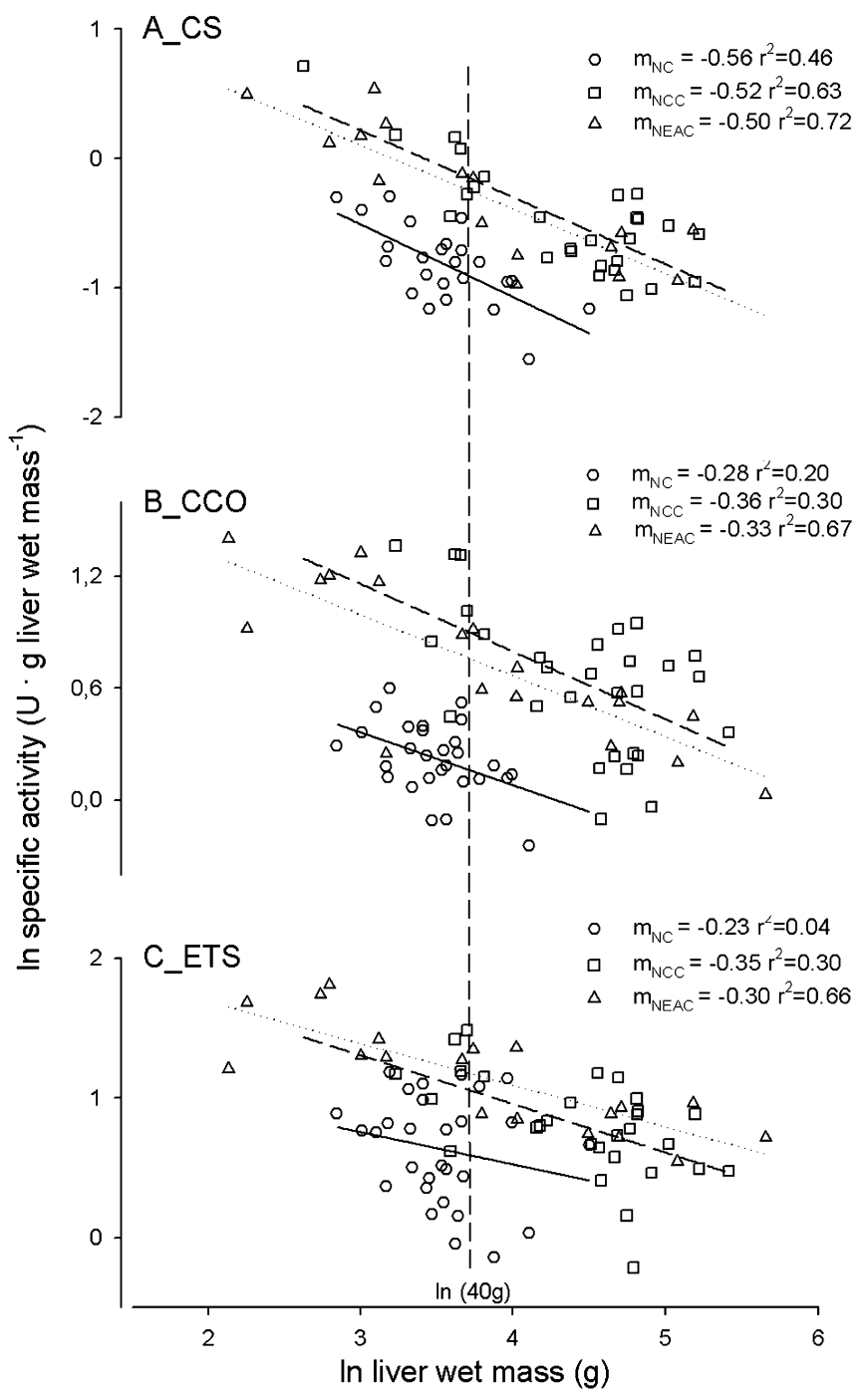

Fig. 1A-C Gadus morhua. Double logarithmic plots of measured specific enzyme activities in liver [citrate synthase $(C S, \mathbf{A})$, cytochrome $c$ oxidase $(C C O, \mathbf{B})$ and electron transport system $(E T S, \mathbf{C})]$ depending on liver mass in grams of different cod populations (circle, $N C$ southern North Sea cod, $n=24-29$; square, NCC Norwegian coastal cod, $n=27-29$; triangle, NEAC northeastern Arctic cod, $n=16-19 ; m$ slopes of the regressions) 
influenced by the lipid contents of the liver we calculated total enzyme activities in whole liver normalized to a $1.2 \mathrm{~kg}$ cod with the following formula:

- normalized activity $=$ total activity in liver $\times(1.2 / \text { body mass })^{m}$, where the body mass exponent $m$ was determined from the slope of the linear regression in a double logarithmic plot of activity in whole liver versus body mass in kilograms (Fig. 2B-D).

Calculation of hepatosomatic index with:

- $I_{\mathrm{H}}=$ liver mass $(\mathrm{g}) /$ body mass $(\mathrm{g}) \times 100$

was done with normalized liver mass for a $1.2 \mathrm{~kg}$ cod by the following formula:

- normalized liver mass $=$ exact liver mass $\times(1.2 / \text { body mass })^{m}$,

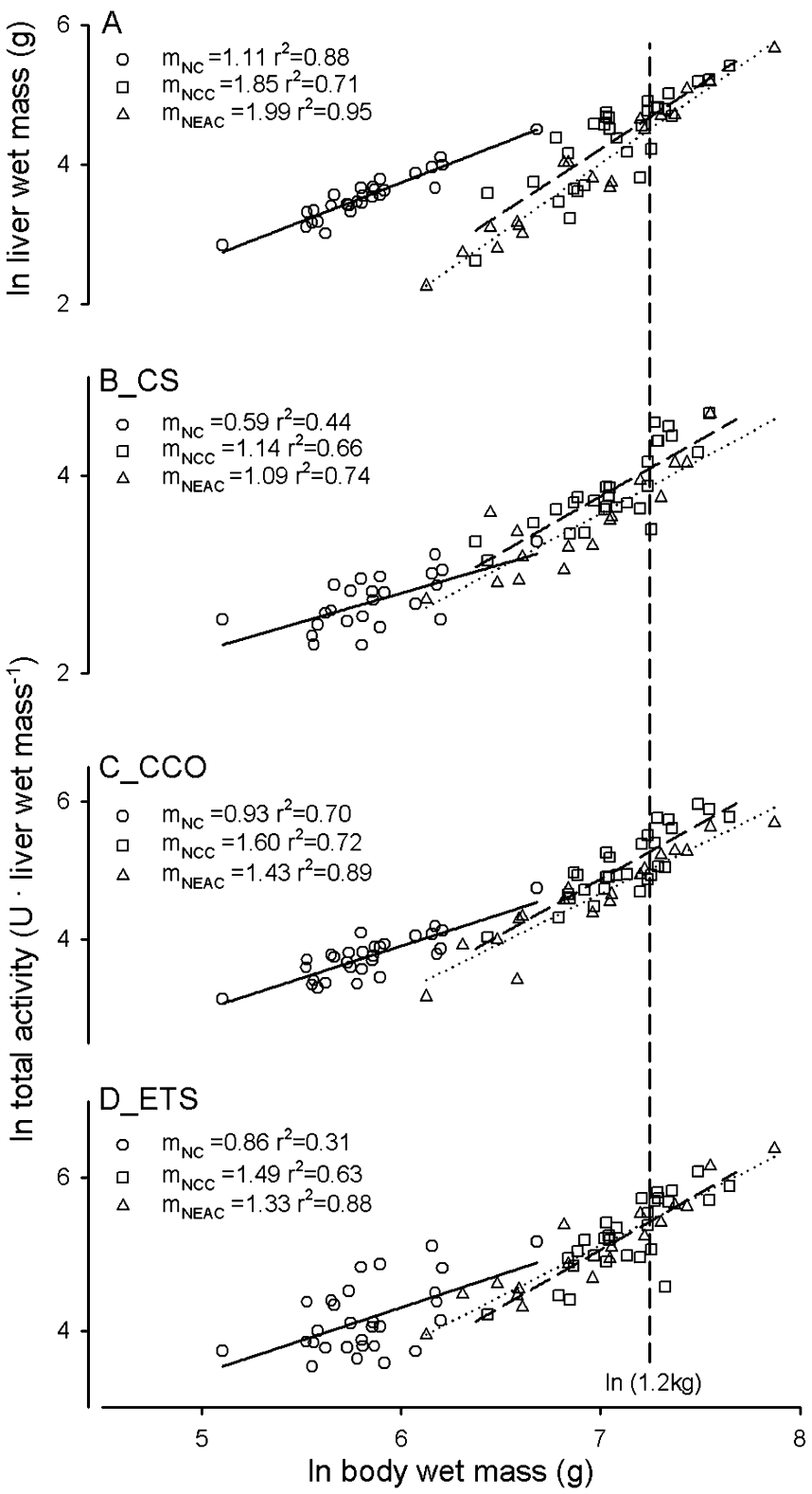

Fig. 2A-D Gadus morhua. Double logarithmic plots of liver mass (A) and enzyme activities in whole liver [citrate synthase $(C S, \mathbf{B})$, cytochrome $c$ oxidase $(C C O, \mathbf{C})$ and electron transport system $(E T S, \mathbf{D})]$ depending on body mass in grams of specimens from different cod populations (circle, $N C$ southern North Sea cod, $n=23-29$; square, NCC Norwegian coastal cod, $n=27-32$; triangle, NEAC northeastern Arctic cod, $n=16-19 ; m$ slopes of the regressions) where the body mass exponent $m$ was determined from the slope of the linear regression in a double logarithmic plot of liver mass versus body mass in kilograms (Fig. 2A).

Since linear regressions were not significantly different between acclimation groups, mass exponents were calculated from regressions for all acclimation groups within one population.

Statistical analyses

All values are given as means ( \pm standard deviation). Statistical significance was tested at the $P=0.05$ level using analysis of variance (ANOVA, SigmaStat) and post hoc procedures (Tukey test). Before statistical testing, log transformations were used, whenever necessary to meet statistical assumptions of the homogeneity of variances. However, non-transformed data are shown in text and figures. The $f$-test was used for regression comparisons.

\section{Results}

White muscle

Activities of CS, CCO and ETS per gram white muscle (normalized to a $1.2 \mathrm{~kg}$ cod, for non-transformed data see Table 2) with respect to acclimation temperature and population are shown in Fig. 3. Cold acclimation $\left(4^{\circ} \mathrm{C}\right.$ and $8^{\circ} \mathrm{C}$ ) led to higher $\mathrm{CS}$ activities than those at $15^{\circ} \mathrm{C}$ in white muscle of all three populations (Fig. 3A). A reduction of environmental temperature from $15^{\circ} \mathrm{C}$ to $4^{\circ} \mathrm{C}$ ( NC and NCC) or $8^{\circ} \mathrm{C}$ (NEAC) caused enzyme activities to rise by a factor of 2.27 for CS, 1.72 for $\mathrm{CCO}$ and 1.65 for ETS in North Sea cod; by a factor of 2.15 for CS, 1.18 for CCO and 1.32 for ETS in Norwegian coastal cod (CCO and ETS not significant); and by a factor of 1.90 for CS, 1.46 for CCO and 1.62 for ETS in northeastern Arctic cod. An acclimation effect was also found for Arrhenius activation energies $\left(E_{\mathrm{a}}\right)$ of CS, with data shown in Table 3. $E_{\mathrm{a}}$ in NC and NEAC increased at cold temperatures, whereas $E_{\mathrm{a}}$ in NCC displayed a non-significant trend to decrease with falling acclimation temperature. The highest $E_{\mathrm{a}}$ levels in the cold $\left(8^{\circ} \mathrm{C}\right)$ were found in NEAC; however, NC displayed higher levels of $E_{\text {a }}$ than $\mathrm{NCC}$ at $4^{\circ} \mathrm{C}$.

An acclimation effect on $\mathrm{CCO}$ activities in white muscle (Fig. 3B) was found for NC and NEAC only, with significantly higher activities at $4^{\circ} \mathrm{C}$ and $8^{\circ} \mathrm{C}$ (NC) and at $8^{\circ} \mathrm{C}$ and $12^{\circ} \mathrm{C}$ (NEAC) compared to $15^{\circ} \mathrm{C}$. CCO activities of Norwegian cod remained unchanged over the range of investigated acclimation temperatures. No significant differences were found between $E_{\mathrm{a}}$ values at various acclimation temperatures within populations or between populations of the same acclimation level. Values varied around $55.92 \pm 3.50 \mathrm{~kJ} \mathrm{~mol}^{-1}$ (measured between $2^{\circ} \mathrm{C}$ and $18^{\circ} \mathrm{C}$, data not shown).

ETS rates in white muscle of all three populations (Fig. 3C) were significantly higher in the cold, with higher activities at $4^{\circ} \mathrm{C}$ and $8^{\circ} \mathrm{C}(\mathrm{NC})$, at $8^{\circ} \mathrm{C}(\mathrm{NCC})$ and at $8^{\circ} \mathrm{C}$ and $12^{\circ} \mathrm{C}$ (NEAC) compared to acclimation at $15^{\circ} \mathrm{C}$.

In a between-population comparison, CS activities tended to be higher in NEAC than in NC and NCC at all 
Table 2 Gadus morhua. Non-transformed enzyme activities in white muscle and liver of cod from different acclimation groups and populations. Data are means $\pm \mathrm{SD}(C S$ citrate synthase; $C C O$ cytochrome $c$ oxidase; ETS electron transport system;)

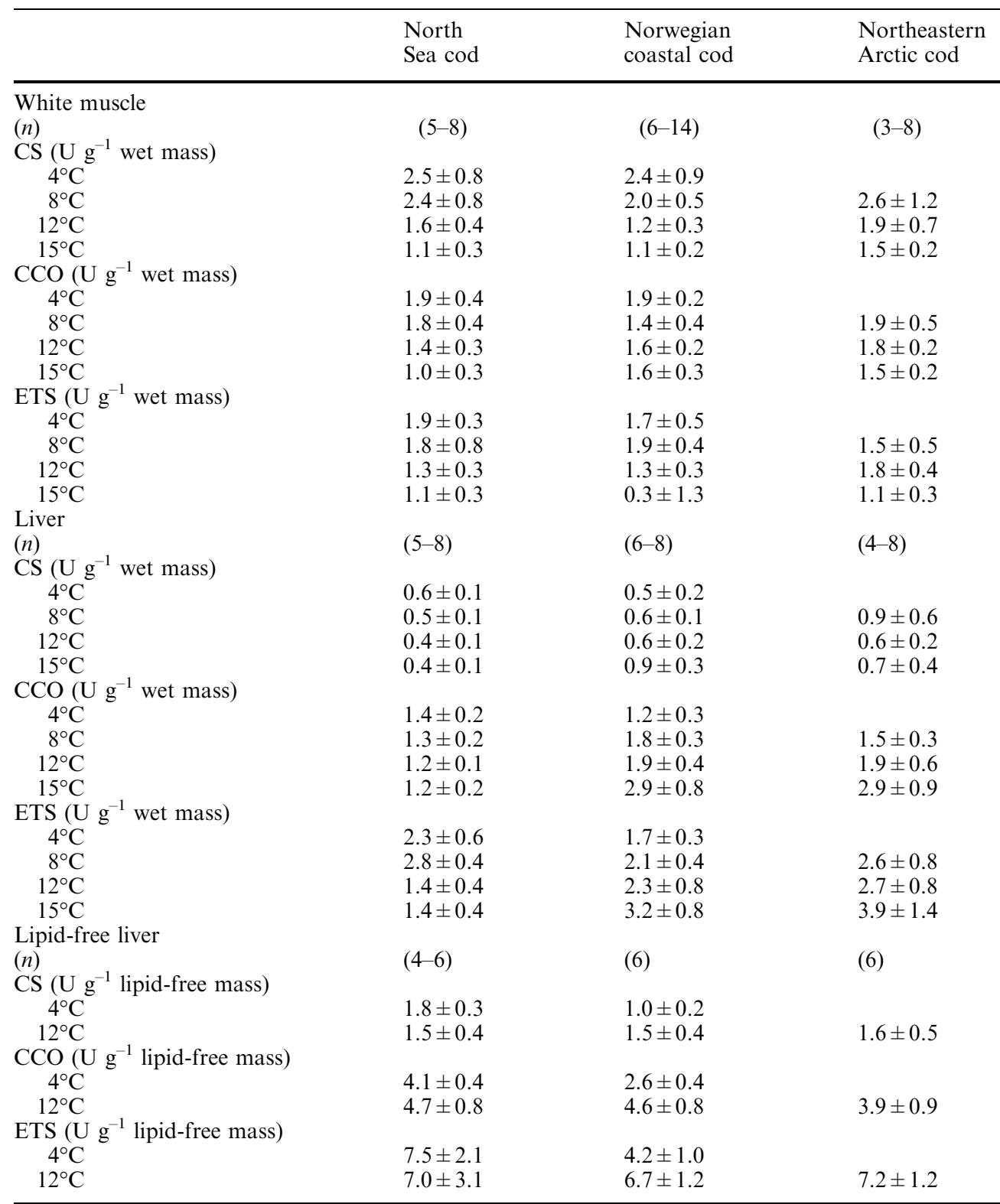

acclimation temperatures, however, differences remained insignificant. At all acclimation temperatures, the population comparisons showed significantly lower CCO activities in white muscle of North Sea cod compared to Norwegian and Arctic cod. Lower ETS rates were found in white muscle of NC compared to NCC at 8,12 and $15^{\circ} \mathrm{C}$ acclimation and compared to NEAC at $12^{\circ} \mathrm{C}$ acclimation only.

Overall, the data suggest enhanced oxidative capacity in white muscle due to permanent cold adaptation in Norwegian coastal and northeastern Arctic cod compared to North Sea cod with mean factors of 1.10 (CS), 1.25 (CCO) and 1.64 (ETS) between $\mathrm{NC}$ and NCC and of 1.37 (CS), 1.59 (CCO) and 1.19 (ETS) between NC and NEAC (calculated for an acclimation temperature of $8^{\circ} \mathrm{C}$ ). For $\mathrm{CS}$ and $\mathrm{CCO}$ activities, a continuum in the level of cold adaptation was apparent that followed the latitudinal cline between $\mathrm{NC}$, NCC and NEAC.

Liver

Weight-specific CS, CCO and ETS activities normalized to $40 \mathrm{~g}$ liver wet weight depending on acclimation temperature and population are shown in Fig. 4. Figure 5 displays total activity in liver normalized to a $1.2 \mathrm{~kg}$ cod. Acclimation effects on CS activity in liver were different between populations. CS of NC showed similar specific activities between acclimation groups (Fig. 4A), but a significant increase with decreasing acclimation temperature became apparent for CS in total liver (Fig. 5A). Norwegian cod acclimated to $4^{\circ} \mathrm{C}$ displayed significantly lower levels of specific CS activity compared to 8, 12 and 


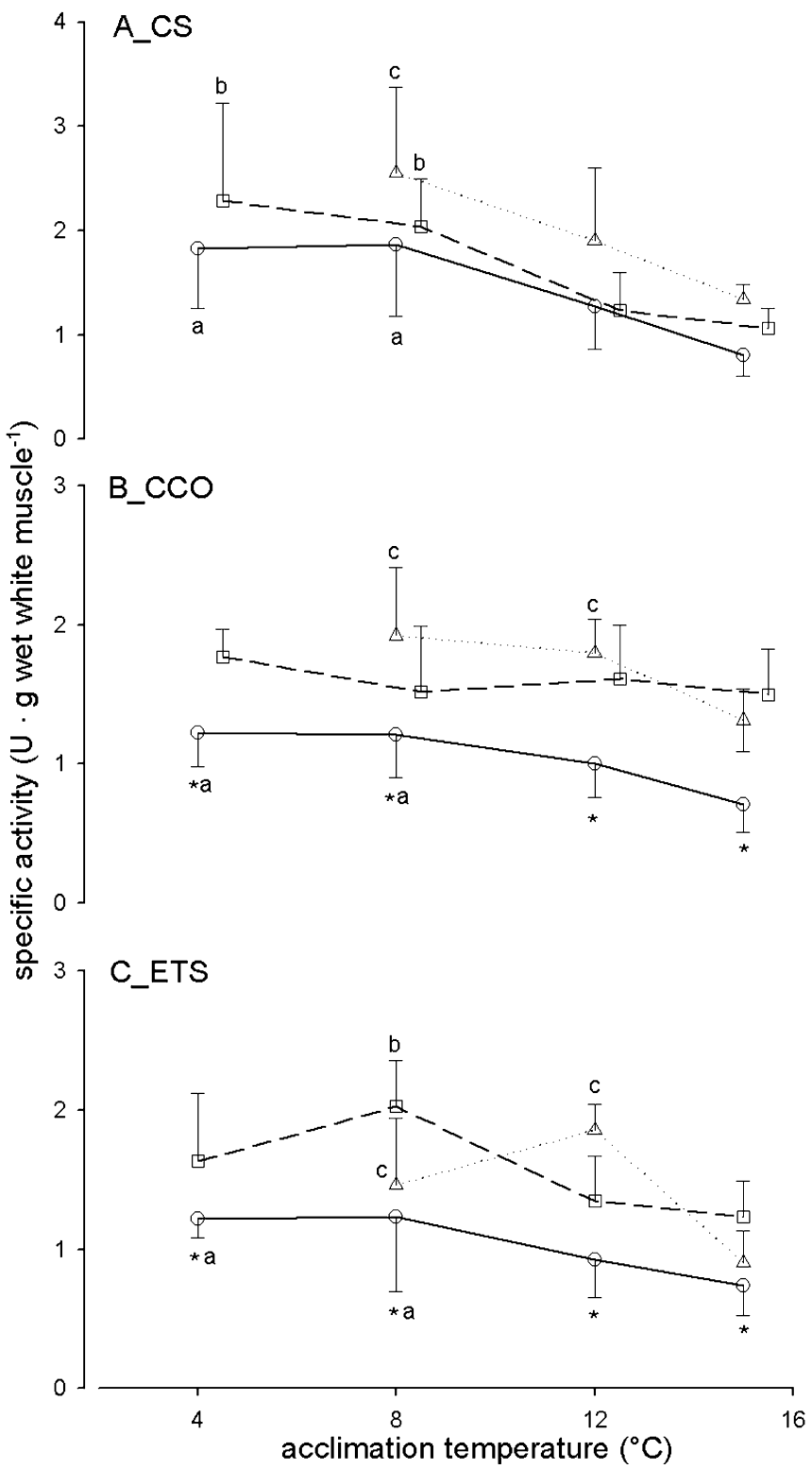

Fig. 3A-C Gadus morhua. Activities of citrate synthase $(C S, \mathbf{A})$, cytochrome $c$ oxidase $(C C O, \mathbf{B})$ and electron transport system $(E T S, \mathbf{C})$ in white muscle (measured at $12^{\circ} \mathrm{C}$ and normalized to $1.2 \mathrm{~kg}$ cod) of different cod populations acclimated to 4, 8, 12 and $15^{\circ} \mathrm{C}$. For better viewing squares were shifted to the right in $\mathrm{A}$ and B (circle southern North Sea cod, $n=5-8$; square Norwegian coastal cod, $n=6-14$; triangle northeastern Arctic cod, $n=3-8 ; a, b$ and $c$ indicate data significantly different from values at $15^{\circ} \mathrm{C}$ for each population; asterisk indicates data of NC significantly different from NCC and NEAC, for ETS the difference to NEAC is significant at $12^{\circ} \mathrm{C}$ only)

$15^{\circ} \mathrm{C}$ (Fig. 4A), but, due to a rise in liver size, similar values in total liver at all acclimation temperatures (Fig. 5A). Both, specific and total CS activities in NEAC liver rose in the cold and were significantly higher at $8^{\circ} \mathrm{C}$ than at $15^{\circ} \mathrm{C}$.

No differences in $E_{\mathrm{a}}$ values were found between acclimation temperatures of the same population and between populations at the same acclimation temperature, with
Table 3 Gadus morhua. Arrhenius activation energies $E_{\mathrm{a}}\left(\mathrm{kJ} \mathrm{mol}^{-1}\right)$ of citrate synthase activity in white muscle of different acclimation groups and populations. Data are means $\pm \mathrm{SD} ; E_{\mathrm{a}}$ values measured between $5^{\circ} \mathrm{C}$ and $18^{\circ} \mathrm{C}$. Means with different superscripts denote significant acclimation effects within one population; means with asterisks differ significantly between populations at the same acclimation temperature

\begin{tabular}{rlcc}
\hline & $\begin{array}{l}\text { North } \\
\text { Sea cod }\end{array}$ & $\begin{array}{l}\text { Norwegian } \\
\text { coastal cod }\end{array}$ & $\begin{array}{l}\text { Northeastern } \\
\text { Arctic cod }\end{array}$ \\
\hline$(n)$ & $(6)$ & $(6-14)$ & $(3-4)$ \\
$4^{\circ} \mathrm{C}$ & $45.3 \pm 6.7^{\mathrm{a} *}$ & $27.3 \pm 8.7^{*}$ & \\
$8^{\circ} \mathrm{C}$ & $31.7 \pm 4.1^{\mathrm{b} *}$ & $32.6 \pm 17.5$ & $54.6 \pm 4.1^{\mathrm{a} *}$ \\
$12^{\circ} \mathrm{C}$ & $33.0 \pm 1.7^{\mathrm{b}}$ & $38.3 \pm 15.1$ & $33.3 \pm 9.9^{\mathrm{b}}$ \\
$15^{\circ} \mathrm{C}$ & $31.9 \pm 1.6^{\mathrm{b}}$ & $43.7 \pm 23.3$ & $35.1 \pm 3.2^{\mathrm{b}}$ \\
\hline
\end{tabular}

average values of about $32.1 \pm 2.3 \mathrm{~kJ} \mathrm{~mol}^{-1}$ for all specimens (measured between $5^{\circ} \mathrm{C}$ and $18^{\circ} \mathrm{C}$, data not shown).

Specific activities of $\mathrm{CCO}$ in liver were similar at the different acclimation temperatures in $\mathrm{NC}$; however, total liver activities tended to rise between $15^{\circ} \mathrm{C}$ and $8^{\circ} \mathrm{C}$. In contrast, $\mathrm{CCO}$ in NEAC was reduced in the cold (Fig. 4B and Fig. 5B, specific and total, respectively). In NCC, specific $\mathrm{CCO}$ was reduced in cold versus warmer acclimation temperatures (Fig. 4B) but remained similar with acclimation in total liver (Fig. 5B).

Specific ETS activities in liver of NC were higher at $4^{\circ} \mathrm{C}$ and $8^{\circ} \mathrm{C}$ compared to $15^{\circ} \mathrm{C}$. Total ETS activities were higher at $8^{\circ} \mathrm{C}$ only compared to $15^{\circ} \mathrm{C}$ and fell again at $4^{\circ} \mathrm{C}$, resulting in no difference to $15^{\circ} \mathrm{C}$. (Fig. $4 \mathrm{C}$ and Fig. 5C, specific and total, respectively). In NCC, specific ETS was significantly lower in cold- versus warm-acclimated fish (Fig. 4C). Total ETS in NCC and specific as well as total ETS in NEAC showed unchanged values between acclimation temperatures.

Differences in CS activities between populations were found at all acclimation temperatures. Specific and total $\mathrm{CS}$ activities in liver of $\mathrm{NC}$ were significantly lower than those of NCC and NEAC. At 8, 12 and $15^{\circ} \mathrm{C}$ specific $\mathrm{CCO}$ and at $12^{\circ} \mathrm{C}$ and $15^{\circ} \mathrm{C}$ specific ETS activities were significantly lower in NC than in NCC and NEAC (Fig. 4B, C); however, this pattern was only apparent at $15^{\circ} \mathrm{C}$ for total liver $\mathrm{CCO}$ and ETS (Fig. 5B, C).

The normalized hepatosomatic index $\left(I_{\mathrm{H}} ;\right.$ Fig. 6) showed no significant acclimation effect in $\mathrm{NC}$ and NEAC (for the latter investigated between $12^{\circ} \mathrm{C}$ and $8^{\circ} \mathrm{C}$ only), but $I_{\mathrm{H}}$ rose in NCC during cold acclimation (Fig. 6). Overall, significantly higher $I_{\mathrm{H}}$ values were found in NC compared to NCC and NEAC.

Lipid and water contents and estimated protein contents of liver for acclimation temperatures of $4^{\circ} \mathrm{C}$ and $12^{\circ} \mathrm{C}$ are shown in Fig. 7 (except those for NEAC at $4^{\circ} \mathrm{C}$ ). $\mathrm{NC}$ livers had significantly more lipid at $12^{\circ} \mathrm{C}$ than at $4^{\circ} \mathrm{C}$, whereas lipid contents of NCC livers remained unchanged at the different temperatures. Population comparisons showed higher liver lipid contents for $\mathrm{NC}$ compared to NCC and NEAC (Fig. 7A), an observation possibly not related to temperature but to the much higher lipid contents in sprats (around 70\%) than in the commercial pellets (around 12\%). The water contents of 

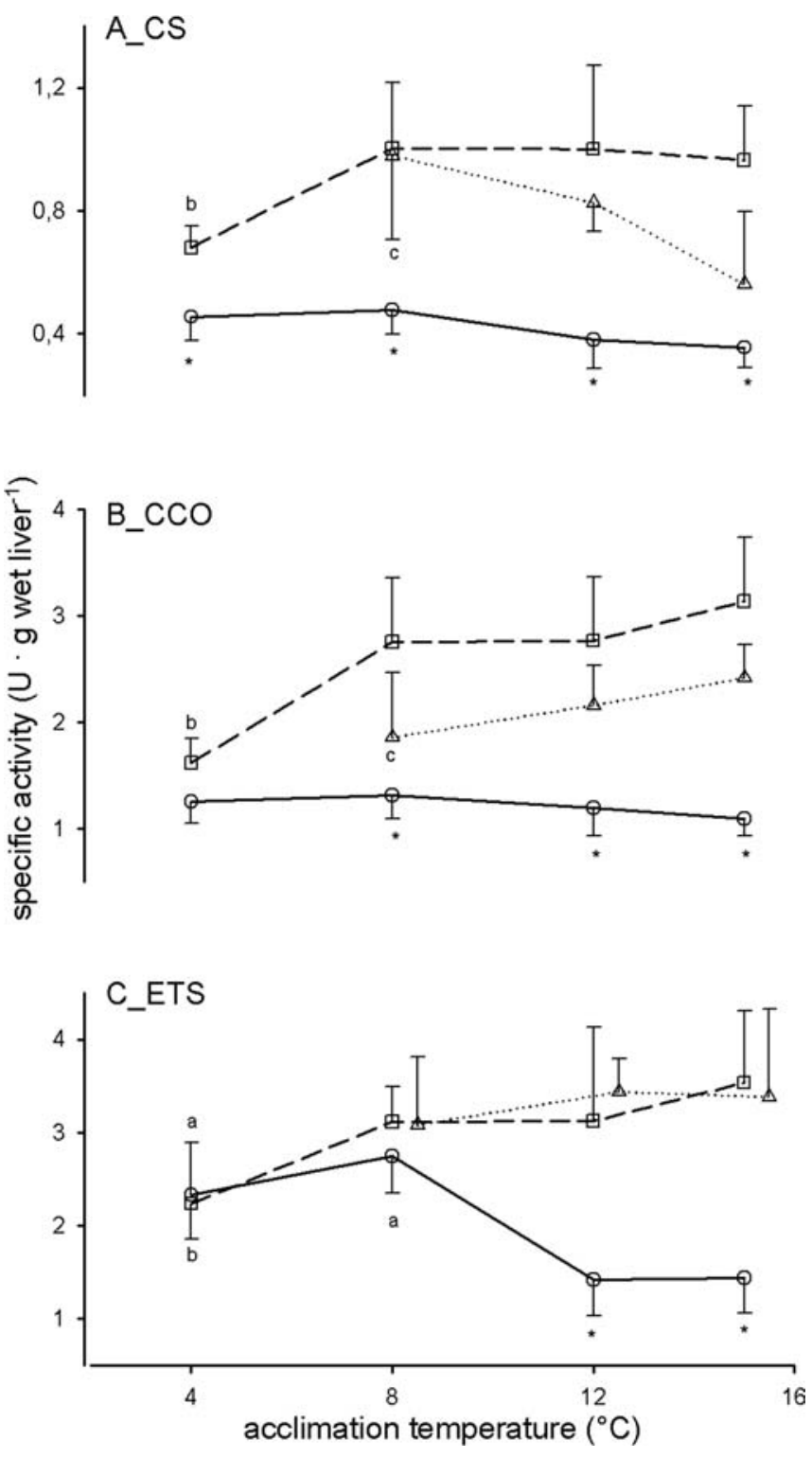

Fig. 4A-C Gadus morhua. Specific activities of citrate synthase $(C S, \mathbf{A})$, cytochrome $c$ oxidase $(C C O, \mathbf{B})$ and electron transport system $\left(E T S\right.$, C) in liver (measured at $12^{\circ} \mathrm{C}$ and normalized to $40 \mathrm{~g}$ liver; ETS values of $\mathrm{NC}$ were not normalized, since the regression in Fig. 1C remained non-significant) of different cod populations acclimated to $4,8,12$ and $15^{\circ} \mathrm{C}$ (circle southern North Sea cod, $n=5-8$; square Norwegian coastal cod, $n=6-14$; triangle northeastern Arctic cod, $n=3-8 ; a$ and $c$ indicate data significantly different from values at $15^{\circ} \mathrm{C}$ for $\mathrm{NC}$ and NEAC; $b$ indicates data significantly different from those at 8,12 and $15^{\circ} \mathrm{C}$ for $\mathrm{NCC}$; asterisk indicates data of $\mathrm{NC}$ significantly different from those of NCC and NEAC at the same acclimation temperature)

liver mirrored the patterns of lipid contents (Fig. 7B), with lower contents in $\mathrm{NC}$ livers at $12^{\circ} \mathrm{C}$ compared to $4^{\circ} \mathrm{C}$, and unchanged values regardless of acclimation temperature in NCC livers. Population comparisons revealed significantly lower liver water contents in $\mathrm{NC}$ compared to NCC and NEAC. The estimated total protein contents of liver showed neither a significant temperature effect nor significant differences between

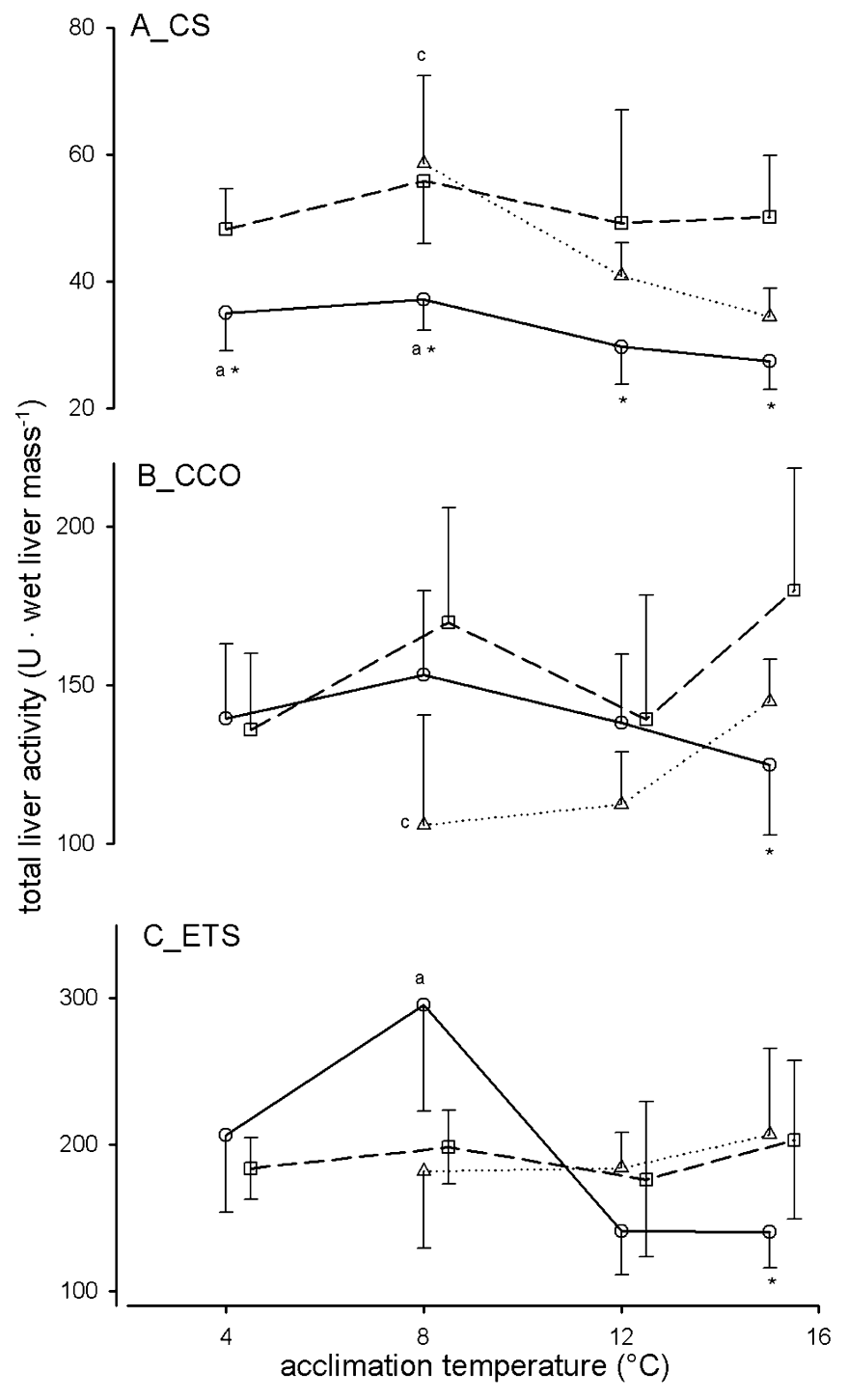

Fig. 5A-C Gadus morhua. Total activities of citrate synthase (CS, A), cytochrome $c$ oxidase $(C C O, \mathbf{B})$ and electron transport system $\left(E T S, \mathbf{C}\right.$ ) in liver (measured at $12^{\circ} \mathrm{C}$ and normalized to a $1.2 \mathrm{~kg}$ cod) of different cod populations acclimated to $4,8,12$ and $15^{\circ} \mathrm{C}$. For better viewing squares were shifted to the right in $\mathrm{B}$ and $\mathrm{C}$ (circle southern North Sea cod, $n=5-8$; square Norwegian coastal cod, $n=6-14$; triangle northeastern Arctic cod, $n=3-8 ; a$ and $c$ indicate data significantly different from values at $15^{\circ} \mathrm{C}$ for $\mathrm{NC}$ and NEAC; asterisk indicates data significantly different from those of other populations at the same acclimation temperature)

populations (Fig. 7C), although due to elevated lipid levels, specific protein contents of $\mathrm{NC}$ livers at $12^{\circ} \mathrm{C}$ tended to be lower than at $4^{\circ} \mathrm{C}$ and also below the total liver protein contents of $\mathrm{NCC}$ and NEAC at $12^{\circ} \mathrm{C}$.

\section{Discussion}

Cold acclimation

Elevated activities of the investigated aerobic enzymes were found after cold acclimation in white muscle of all 


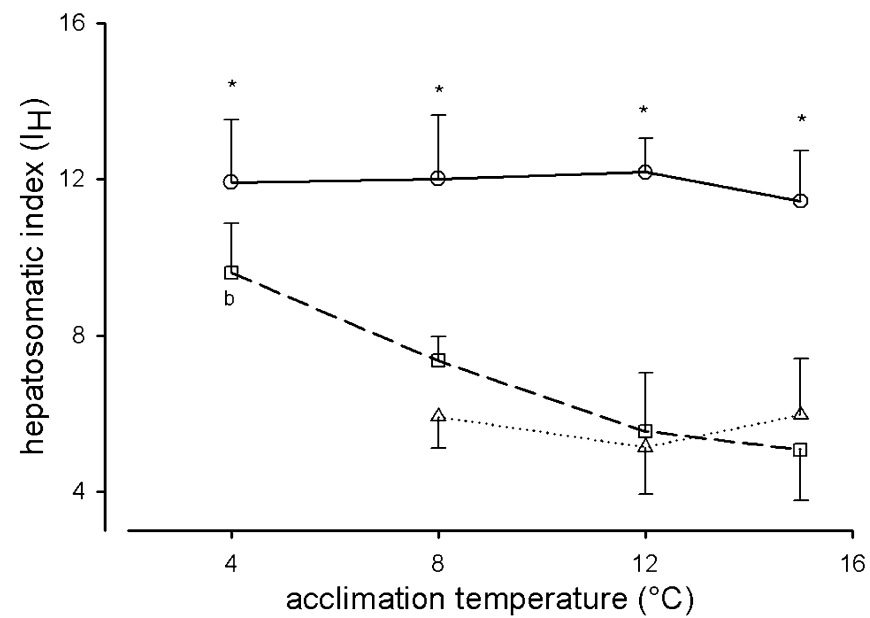

Fig. 6 Gadus morhua. Hepatosomatic index $\left(I_{\mathrm{H}}\right.$, normalized to a $1.2 \mathrm{~kg}$ cod) of different cod populations acclimated to $4,8,12$ and $15^{\circ} \mathrm{C}$ ( circle southern North Sea cod, $n=4-8$; square Norwegian coastal cod, $n=6-9$; triangle northeastern Arctic cod, $n=5-7 ; b$ indicates data significantly different from those at $12^{\circ} \mathrm{C}$ and $15^{\circ} \mathrm{C}$ for NCC; asterisk indicates data of NC significantly different from those of NCC and NEAC at the same acclimation temperature)

cod populations (Fig. 3). Factorial increments were in the medium range compared to those described for other fish species. Usually, factorial changes were lower for CCO and ETS than for CS activities. An excess capacity of citrate synthase in the cold might provide excess citrate for enhanced lipid biosynthesis (for review cf. Pörtner 2002a,b). For comparison, cold acclimation also led to higher CS activities in axial and pectoral muscle of threespine stickleback, Gasterosteus aculeatus (Guderley and Leroy 2001), by a factor of approximately 2 (axial) and 1.5 (pectoral) and in muscle of rainbow trout, Oncorhynchus mykiss, by a factor of 2.82 (white muscle) and 3.98 (red muscle) (Cordiner and Eggington 1997). These changes are reversed during heat exposure as in white sucker, Castotomus commersoni, where CS activity in white muscle fell by around $30 \%$ during the first day and remained constant thereafter (Hardewig et al. 2000). Elevated CCO activities in white muscle after cold acclimation were found in North Sea eelpout, Zoarces viviparus (Hardewig et al. 1999), and in juvenile cod, Gadus morhua (Foster et al. 1993), as well as in red muscle of cold-acclimated carp, Cyprinus carpio L. (Wodtke 1981). Van den Thillart and Modderkolk (1978) found a significant increase in CCO activities, which was accompanied by a parallel increase of mitochondrial respiration rates (state III, ADP-activated) per gram red and white muscle of goldfish, Carassius auratus auratus, with decreasing acclimation temperature.

$\mathrm{CCO}$ and ETS activities (the latter measured as the combined activities of complex I and III) as measures of oxidative capacity have been investigated in many tissues and whole organisms from plankton to mammals (Jansky 1961; Simon and Robin 1971; Ikeda 1989; Elderkin et al. 1998); however, very little information is available for the response of ETS activities to tempera-
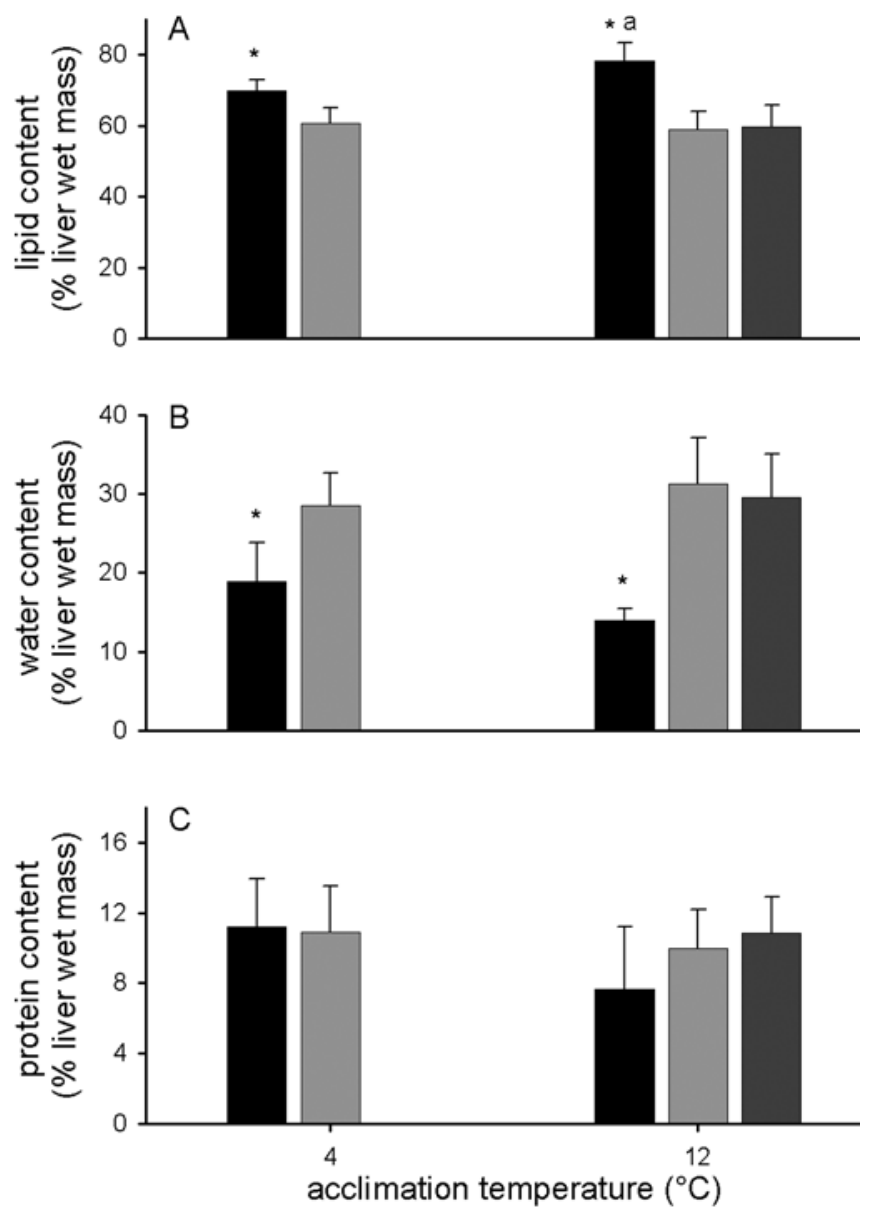

Fig. 7A-C Gadus morhua. Total lipid (A), water (B) and protein contents (C) of liver of different cod populations acclimated to $4^{\circ} \mathrm{C}$ and $12^{\circ} \mathrm{C}$ (black southern North Sea cod, $n=4-8$; light gray Norwegian coastal cod, $n=4-9$; dark gray northeastern Arctic cod, $n=5-7 ; a$ indicates data significantly different from those at $4^{\circ} \mathrm{C}$ for $\mathrm{NC}$; asterisk indicates data of NC significantly different from those of NCC and NEAC at the same acclimation temperature)

ture in animals. Tully et al. (2000) estimated metabolic rate responses to changes in temperature by measuring ETS activity (combined complex I, II and III) in abdominal muscle of lobster, Homarus gammarus. They found similar ETS activities in muscle of cold- $\left(8^{\circ} \mathrm{C}\right)$ and warm-acclimated $\left(18^{\circ} \mathrm{C}\right)$ lobster when assayed at $13^{\circ} \mathrm{C}$, indicating no compensation for changes in environmental temperature. These findings are in contrast to our demonstration of cold-compensated ETS activities in cod white muscle (Fig. 3C). The poor compensation ability of lobsters is consistent with the well-described seasonality in their activity, growth and depth distribution (Tully et al. 2000). In our study, CS, CCO and ETS activities in white muscle changed in parallel. This indicates that aerobic capacities of white muscle are enhanced in cold-acclimated cod.

In liver, enzyme activities failed to show such a clear pattern of cold acclimation. Specific CS and CCO activities in liver of $\mathrm{NC}$ remained unchanged at the different acclimation temperatures, and only specific ETS 
was enhanced in the cold. However, total liver CS of NC rose with cold acclimation, whereas total $\mathrm{CCO}$ and likely ETS remained unchanged over the investigated acclimation range. In NCC, all enzymes even showed lower specific activities at $4^{\circ} \mathrm{C}$ compared to 8,12 and $15^{\circ} \mathrm{C}$, whereas total enzyme activities remained similar during acclimation, due to the rise in liver mass. In NEAC, specific and total CS activities were enhanced after cold acclimation, whereas CCO and ETS activities decreased with decreasing acclimation temperature (not significant for ETS). A lack of change or even a loss of specific CCO activities ( $\mathrm{U} \mathrm{g}^{-1}$ liver) had also been shown in liver of cold-acclimated eelpout, Z. viviparus (Hardewig et al. 1999), goldfish, C. auratus (van den Thillart and Modderkolk 1978), and ide, Leuciscus idud melanotus (Rafael and Braunbeck 1988). In cold-acclimated channel catfish, Ictalurus punctatus, Kent et al. (1988) found a positive compensation of total liver CS activities, whereas total $\mathrm{CCO}$ remained similar between fish acclimated to $25^{\circ} \mathrm{C}$ and $15^{\circ} \mathrm{C}$. Comparisons of specific activities and DNA content based on liver wet mass showed no compensation of CS activity, whereas CCO activity and DNA content were reduced in the cold. Furthermore, the authors found increased CS in the cold but decreased $\mathrm{CCO}$ when based on milligrams liver protein and increased CS but similar CCO activities when based on milligrams liver DNA. Overall, their findings were related to a twofold increase in liver mass in the cold accompanied by an increase of total protein leaving protein concentrations per gram tissue unchanged.

These observations in liver are principally in line with the trends in cod white muscle for CS on the one hand and for CCO and ETS on the other. CS showed stronger cold compensation than the membrane-bound systems. Hepatic-specific activities of the latter even appear to fall during cold acclimation in the Northern cod populations, as observed in cold-acclimated catfish. This trend was linked to increasing liver size (at unchanged lipid levels) in $\mathrm{NCC}$, but not (between $15^{\circ} \mathrm{C}$ and $8^{\circ} \mathrm{C}$ ) in NEAC. Since no data are available for NEAC acclimated to $4^{\circ} \mathrm{C}$, comparison with this population is outside its normal temperature range. A rise in $I_{\mathrm{H}}$ similar to that observed in NCC can therefore not be excluded during extreme cold acclimation of NEAC (Fig. 6). In $\mathrm{NC}$ an increase in functional liver size in the cold appears likely, but was hidden by the concomitant drop in lipid levels. Here, total CS activity (Fig. 5A) was enhanced in the cold, with a concomitant increase in liver protein. Similar to the catfish, no acclimation effects were found on total $\mathrm{CCO}$ (Fig. 5B) despite enhanced liver protein content (Fig. 7C). A rise in total ETS was only observed at $8^{\circ} \mathrm{C}$. This result likely reflects a decrease of specific enzyme activities per milligram tissue protein as described by Kent et al. (1988) for catfish (see above).

In NEAC, total CS activities were more enhanced in the cold than in NC (Fig. 5A). Since liver-mass-specific CS activities (Fig. 4A) were also higher in the cold, a rise in enzyme number and/or enzyme turnover number may have occurred during cold acclimation of NEAC. The concomitant drop in CCO activity again suggests a metabolic reorganization of cold-acclimated mitochondria, emphasizing the general trend discussed above. Aerobic capacity (state III respiration) of mitochondria reflects the integration of the isolated systems into the larger unit. In fact, the degree of cold compensation of state III respiration of isolated liver mitochondria after acclimation to $4^{\circ} \mathrm{C}$ was small in both $\mathrm{NC}$ and NEAC (T. Fischer, G. Lannig, R. Knust, H.O. Pörtner, unpublished data), a finding in line with the picture drawn here. Capacity increments at the mitochondrial level are most strongly suggested by the rise in CS activities in both NC and NEAC in the cold, but the functional impact of this rise may be compromised to some extent by falling CCO and ETS levels. CS, CCO and ETS activities in NCC indicate unchanged or even falling aerobic capacities during cold acclimation, where a drop in liver-mass-specific rates is compensated for by a rise in liver size.

\section{Cold adaptation}

The findings of permanent cold compensation in NCC and NEAC white muscle are consistent with inter-specific comparisons by Crockett and Sidell (1990), who found 1.5- to 5-fold higher CS and CCO activities in muscles from sluggish, bottom-dwelling as well as from more active, pelagic Antarctic species (Notothenia gibberifrons, Trematomus newnesi) compared to their temperate counterparts (Myoxocephalus octodecimspinosus, Tautoga onitis). Cold compensation linked to enhanced CS activities in white muscle of Antarctic compared to California mesopelagic fishes was also observed by Torres and Somero (1988). In contrast, comparisons of enzyme activities in Antarctic and tropical fish by Kawall et al. (2002) failed to show cold compensation in white muscle, likely due to different lifestyles (lower activity rates in Antarctic fish), but clear evidence for cold compensation in the polar species was visible when brain CS activities were compared.

In liver, once again, the picture is less clear, owing to parallel changes in organ size, composition and enzyme capacities. Liver-mass-specific levels of all enzymes increase between NC, NEAC and then NCC (Fig. 4) for ETS at $12^{\circ} \mathrm{C}$ and $15^{\circ} \mathrm{C}$ acclimation only. Some of this is due to different lipid levels, which were high especially in NC (Fig. 7A). Accordingly, total liver capacities are no longer as clearly different, especially for CCO and ETS. Ratios of total enzyme activities between populations after $8^{\circ} \mathrm{C}$ and $15^{\circ} \mathrm{C}$ acclimation are shown in Table 4 and provide clear evidence for positive cold compensation in total CS activities due to permanent cold adaptation independent of acclimation temperature. However, no significant differences between total $\mathrm{CCO}$ and ETS activities of populations were seen at $8^{\circ} \mathrm{C}$, whereas at $15^{\circ} \mathrm{C}$ total levels were higher in NEAC and 
Table 4 Gadus morhua. Ratios of total enzyme activities in liver of different cod populations acclimated to $8^{\circ} \mathrm{C}$ and $15^{\circ} \mathrm{C}(C S$ citrate synthase; $C C O$ cytochrome $c$ oxidase; ETS electron transport system; asterisk indicates significantly enhanced ratios)

\begin{tabular}{llllll}
\hline & \multicolumn{2}{l}{ Norwegian: North Sea } & & \multicolumn{2}{l}{ Arctic: North Sea } \\
\cline { 2 - 3 } \cline { 5 - 6 } & $8^{\circ} \mathrm{C}$ & $15^{\circ} \mathrm{C}$ & & $8^{\circ} \mathrm{C}$ & $15^{\circ} \mathrm{C}$ \\
\hline $\mathrm{CS}$ & $1.5^{*}$ & $1.8^{*}$ & & $1.6^{*}$ & $1.3^{*}$ \\
CCO & 1.1 & $1.4^{*}$ & & 0.7 & $1.2^{*}$ \\
ETS & 0.7 & $1.5^{*}$ & & 0.6 & $1.5^{*}$ \\
\hline
\end{tabular}

NCC than in NC. These findings again suggest distinct changes of CS on the one hand and of respiratory chain components on the other, as discussed in the context of cold acclimation (see previous subsection). Data on isolated mitochondria in NC and NEAC (T. Fischer, G. Lannig, R. Knust, H.O. Pörtner, unpublished data) emphasize that elevated liver-mass-specific activities, especially of CS, but also of CCO and ETS, are in line with highly cold-compensated mitochondrial capacities in the northern cod populations. Total hepatic capacities of CCO and ETS were similar or even lower (in the case of CCO in NEAC) in cold- compared to warm-adapted cod, counteracting the effect of enhanced CS levels. Nonetheless, they may still allow for some rise in liver total aerobic capacity and may be further influenced by population-specific changes in membrane properties.

\section{Metabolic control in the cold}

Enhanced enzyme capacities in white muscle in the cold, as found in cold-acclimated as well as in cold-adapted cod, indicate a rise in aerobic capacity due to either mitochondrial proliferation or enhanced capacities of individual mitochondria; both mechanisms are likely involved. Mitochondrial proliferation has been found in cold-acclimated eurythermal (Campbell and Davies 1978; Egginton and Sidell 1989) as well as in coldadapted, Southern and Northern Hemisphere species (Londraville and Sidell 1990; Johnston et al. 1998; Sommer and Pörtner 2002).

A mechanism involved in capacity changes of individual enzymes is the minimization or maximization of Arrhenius activation energy $\left(E_{\mathrm{a}}\right)$ (Hochachka and Somero 1984; Pörtner et al. 2000; Pörtner 2002a). The traditional understanding is that $E_{\mathrm{a}}$ falls in the cold, indicated by a drop in $E_{\mathrm{a}}$ values of a wide range of enzymes (Hazel and Prosser 1974). This picture has recently been questioned, and it has been argued that a rise in $E_{\mathrm{a}}$ of non-equilibrium enzymes like isocitrate dehydrogenase, in mitochondrial proton leakage and, in consequence, in mitochondrial and whole-animal oxygen demand contributes to low energy turnover in polar, especially Antarctic, species and explains the level of extreme stenothermy (Pörtner et al. 2000; Pörtner 2002a). The higher $E_{\mathrm{a}}$ of CS (Table 3) in coldversus warm-acclimated white muscle of $\mathrm{NC}$ and
NEAC, being also higher in cold-adapted NEAC compared to cold-acclimated NC, may serve to limit some of the enhanced metabolic flux caused by mitochondrial proliferation.

\section{Cost of cold compensation}

In cod, liver is the primary site of lipid storage (Love 1970; Lambert and Dutil 1997). As food composition differed between $\mathrm{NC}$ on the one hand and NEAC and NCC on the other hand, temperature-induced modifications of lipid content can reliably be analyzed only within populations. In accordance with the much higher lipid contents of sprats, comparison between populations revealed significantly lower liver lipid contents in cold-adapted (NCC and NEAC) versus boreal cod (NC) regardless of acclimation temperature. Different gonadosomatic indices $\left(I_{\mathrm{G}}\right.$; Table 1$)$ may also explain some of the differences in hepatic lipid content between populations.

However, significantly lower hepatic lipid contents were also found in cold-compared to warm-acclimated $\mathrm{NC}$, reflecting lower energy reserves in the cold despite unlimited food availability (Fig. 7A). This effect was not found in NCC, which showed similar lipid levels at $4^{\circ} \mathrm{C}$ and $12^{\circ} \mathrm{C}$ acclimation. Considering its enhanced $I_{\mathrm{H}}$ at low acclimation temperatures, NCC were able to accumulate more lipid at $4^{\circ} \mathrm{C}$ than at $12^{\circ} \mathrm{C}$. A cold-induced shift to lipid anabolism and turnover appears typical for cold-adapted species (for review cf. Pörtner 2002b).

Overall, our findings of elevated aerobic capacities in the cold are in line with the hypothesis that life in the cold is more costly at high northern latitudes due to the eurythermy of many Arctic and sub-Arctic species, in contrast to the largely stenothermal Antarctic fauna (Pörtner et al. 2000, 2001; Pörtner 2002a,b). Mitochondrial proliferation and the cost of maintenance of a higher number of mitochondria [e.g. maintenance of ion (proton) gradients] and aerobic enzyme capacities would contribute to a rise (a higher "idling") of basal metabolism (for review see Pörtner et al. 2000; Pörtner 2002a,b). This increase would cause a shift in energy budget, unfavorable to the accumulation of energy reserves, for growth and for reproduction. Accordingly, elevated maintenance costs could explain lower liver lipid contents in cold-acclimated NC (Fig. 7A). Moreover, Pörtner et al. (2001) found that growth performance in NC, NCC and NEAC, acclimated to $4,8,12$ and $15^{\circ} \mathrm{C}$, was optimal close to $10^{\circ} \mathrm{C}$ for all populations. However, temperature-specific growth decreased at higher latitudes. Certainly, mitochondrial changes are only part of the overall picture, but it is crucial to understand adjustments of aerobic capacities in cold-acclimated and cold-adapted animals. Further effort is required to investigate the mechanistic links between enzyme capacities and whole-animal oxygen demand in more detail and to come to a more complete understanding of the mechanisms of thermal adaptation, 
their constraints and limitations as well as their energetic consequences.

Acknowledgements A contribution to the ELOISE project: "Effects of climate induced temperature change on marine coastal fishes (CLICOFI)", funded by the European Union program "Climate and environment", contract no. ENV4-CT97-0596. The authors wish to thank W. Wosniok (Institute for Statistics, University Bremen) for helping in the statistical and allometric series. The authors hereby declare that experiments performed during this study comply with current legislation.

\section{References}

Bligh E, Dyer W (1959) A rapid method of total lipid extraction and purification. Can J Biochem Physiol 37:911-917

Campbell C, Davies P (1978) Temperature acclimation in the teleost, Blennius pholis: changes in enzyme activity and cell structure. Comp Biochem Physiol B 61:165-167

Cordiner S, Eggington S (1997) Effect of seasonal temperature acclimatization on muscle metabolism in rainbow trout, Oncorhynchus mykiss. Fish Physiol Biochem 16:333-343

Crockett EL, Sidell BD (1990) Some pathways of energy metabolism are cold adapted in antarctic fishes. Physiol Zool 63:472-488

Egginton S, Sidell B (1989) Thermal acclimation induces adaptive changes in subcellulas structure of fish skeletal muscle. Am J Physiol 256:R1-R10

Elderkin C, Schneider D, Stoeckel J, Padilla D (1998) A method for measuring in situ oxygen consumption rates of freshwater gastropods. J North Am Benthol Soc 17:338-347

Foster AR, Hall SJ, Houlihan DF (1993) The effect of temperature acclimation on organ/tissue mass and cytochrome $c$ oxidase activity in juvenile cod (Gadus morhua). J Fish Biol 42:947-957

Guderley H, Leroy P (2001) Family origin and the response of threespine stickleback, Gasterosteus aculeatus, to thermal acclimation. J Comp Physiol B 171:91-101

Hardewig I, van Dijk PLM, Moyes CD, Pörtner HO (1999) Temperature-dependent expression of cytochrome- $c$ oxidase in Antarctic and temperate fish. Am J Physiol 277:R508R516

Hardewig I, van Dijk PLM, Leary SC, Moyes CD (2000) Temporal changes in enzyme activity and mRNA levels during thermal challenge in white sucker. J Fish Biol 56:196-207

Hazel JR, Prosser CL (1974) Molecular mechanisms of temperature compensation in poikilotherms. Physiol Rev 54:620-676

Hochachka PW, Somero GN (1984) Biochemical adaptation. Princeton University Press, Princeton, N.J.

Ikeda T (1989) Estimated respiration rate of myctophid fish from the enzyme activity of the electron-transport-system. J Oceanogr Soc Jpn 45:167-173

Jansky L (1961) Total cytochrome oxidase activity and its relation to basal and maximal metabolism. Nature 189:921-922

Johnston IA, Calvo J, Guderley H, Fernandez D, Palmer L (1998) Latitudinal variation in the abundance and oxidative capacities of muscle mitochondria in perciform fishes. J Exp Biol 201:1-12

Kawall HG, Torres JJ, Sidell BD, Somero GN (2002) Metabolic cold adaptation in Antarctic fishes: evidence from enzymatic activities of brain. Mar Biol 140:279-286

Kent J, Koban M, Prosser C (1988) Cold-acclimation-induced protein hypertrophy in channel catfish and green sunfish. J Comp Physiol B 158:185-198

Lambert Y, Dutil J (1997) Can simple indices be used to monitor and quantify seasonal changes in the energy reserves of cod (Gadus morhua)? Can J Fish Aquat Sci 54:104-112

Londraville R, Sidell B (1990) Ultrastructure of aerobic muscle in Antarctic fishes may contribute to maintenance of diffusion fluxes. J Exp Biol 150:205-220

Love R (1970) The chemical biology of fishes. Academic, New York
Madon SP, Schneider DW, Stoeckel JA (1998) In situ estimation of zebra mussel metabolic rates using the electron transport system (ETS) assay. J Shellfish Res 17:195-203

Moyes CD, Mathieu-Costello OA, Tsuchiya N, Filburn C, Hansford RG (1997) Mitochondrial biogenesis during cellular differentiation. Am J Physiol 272:1345-1354

Nielsen EE, Hansen MM, Schmidt C, Meldrup D, Gronkjaer P (2001) Population of origin of Atlantic cod. Nature 413:272

Pelletier D, Guderley H, Dutil JD (1993) Does the aerobic capacity of fish muscle change with growth rates? Fish Physiol Biochem 12:83-93

Pörtner HO (2002a) Climate variations and the physiological basis of temperature dependent biogeography: systemic to molecular hierarchy of thermal tolerance in animals. Comp Biochem Physiol A 132:739-761

Pörtner H (2002b) Physiological basis of temperature dependent biogeography: tradeoffs in muscle design and performance in polar ectotherms. J Exp Biol 205:2517-2530

Pörtner HO, van Dijk PLM, Hardewig I, Sommer A (2000) Levels of metabolic cold adaptation: tradeoffs in eurythermal and stenothermal ectotherms. In: Davison W, Williams CW (eds) Antarctic ecosystems: models for a wider understanding. Caxton, Christchurch, New Zealand, pp 109-122

Pörtner HO, Berdal B, Blust R, Brix O, Colosimo A, De Wachter B, Giuliani A, Johansen T, Fischer T, Knust R, Lannig G, Naevdal G, Nedenes A, Nyhammer G, Sartoris FJ, Serendero I, Sirabella P, Thorkildsen S, Zakhartsev M (2001) Climate induced temperature effects on growth performance, fecundity and recruitment in marine fish: developing a hypothesis for cause and effect relationships in Atlantic cod (Gadus morhua) and common eelpout (Zoarces viviparus). Cont Shelf Res 21:1975-1997

Rafael J, Braunbeck T (1988) Interacting effects of diet and environmental temperature on biochemical parameters in the liver of Leuciscus idud melanotus (Cyprinidae: Teleostei). Fish Physiol Biochem 5:9-19

Seddon W, Prosser C (1997) Seasonal variations in the temperature acclimation response of the channel catfish, Ictalurus punctatus. Physiol Zool 70:33-44

Sidell BD, Driedzic WR, Stowe DB, Johnston IA (1987) Biochemical correlations of power development and metabolic fuel preferenda in fish hearts. Physiol Zool 60:221-232

Simon L, Robin E (1971) Relationship of cytochrome oxidase activity to vertebrate total and organ oxygen consumption. Int $\mathbf{J}$ Biochem 2:569-573

Sokolova IM, Pörtner HO (2001) Temperature effects on key metabolic enzymes in Littorina saxatilis and L. obtusata from different latitudes and shore levels. Mar Biol 139:113-126

Sommer AM, Pörtner H-O (2002) Metabolic cold adaptation in the lugworm Arenicola marina (L.): comparison of a White Sea and a North Sea population. Mar Ecol Prog Ser 240:171-182

St-Pierre J, Charest P-M, Guderley H (1998) Relative contribution of quantitative and qualitative changes in mitochondria to metabolic compensation during seasonal acclimation of rainbow trout Oncorhynchus mykiss. J Exp Biol 201:2961-2970

Torres J, Somero G (1988) Metabolism, enzymic activities and cold adaptation in Antarctic mesopelagic fishes. Mar Biol 98:169180

Tully O, O'Donovan V, Fletcher D (2000) Metabolic rate and lipofuscin accumulation in juvenile European lobster (Homarus gammarus) in relation to simulated seasonal changes in temperature. Mar Biol 137:1031-1040

van den Thillart G, Modderkolk J (1978) The effect of acclimation temperature on the activation energies of state III respiration and on the unsaturation of membrane lipids of goldfish mitochondria. Biochim Biophys Acta 510:38-51

Wodtke E (1981) Temperature adaptation of biological membranes. Compensation of the molar activity of cytochrome $c$ oxidase in the mitochondrial energy-transducing membrane during thermal acclimation of the carp (Cyprinus carpio L.). Biochim Biophys Acta 640:710-720 